\title{
Studi In Silico Senyawa Alkaloid Herba Bakung Putih (Crinum Asiaticum L.) pada Penghambatan Enzim Siklooksigenase (COX)
}

\section{In Silico Study of Alkaloid Herba Bakung Putih (Crinum Asiaticum L.) on Inhibition of Cyclooxygenase Enzyme (COX)}

\author{
Rizky Arcinthya Rachmania, Hariyanti, Ririh Zikriah, Aditya Soultan \\ Program Studi Farmasi, Fakultas Farmasi dan Sains, Universitas Muhammadiyah Prof. Dr. HAMKA, Islamic \\ Center, Jl. Delima II/IV Perumnas Klender, Jakarta Timur, 13460, Telp. (021) 8611070 \\ Email : arcinthya.rizky@gmail.com
}

Received: April 2018; Revised: July 2018; Accepted: November 2018; Available Online: November 2018

\begin{abstract}
Abstrak
Inflamasi merupakan suatu respon terhadap cedera jaringan yang melibatkan proses fisiologis aktivasi enzim siklooksigenase (COX) yang memiliki dua isoform yaitu enzim siklooksigenase-1 (COX-1) dan siklooksigenase2 (COX-2). Penggunaan obat antiinflamasi golongan Anti Inflamasi Non Steroid (AINS) dan golongan steroid mempunyai efek samping dalam penggunaan jangka panjang. Tujuan penelitian ini adalah untuk mengetahui delapan senyawa alkaloid aktif herba bakung putih (Crinum asiaticum L.) untuk digunakan sebagai antiinflamasi dengan cara menghambat enzim COX-1 dan COX-2. Metode penambatan molekul (molecular docking) untuk prediksi struktur kompleks senyawa-protein yang dinamakan docking ligan-protein menggunakan software PLANTS 1.2. dimana skor ChemPLP terendah yang merupakan energy bebas adalah parameter penambatan molekul. Senyawa herba bakung putih yang memperoleh skor CHEMPLP terendah yaitu hippadine -83.3684 $\mathrm{Kkal} / \mathrm{mol}$ dan pratorimin $-83.2661 \mathrm{Kkal} / \mathrm{mol}$ serta pembanding aspirin $-67.3292 \mathrm{Kkal} / \mathrm{mol}$ dan paracetamol 66.3535 Kkal/mol. Penambatan molekul pada COX-2 menunjukkan lycobetaine $-87.3991 \mathrm{Kkal} / \mathrm{mol}$ lebih rendah daripada senyawa pembanding celecoxib -85.3729 Kkal/mol terhadap reseptor siklooksigenase-2 (COX-2). Hasil ini menunjukkan senyawa alkaloid bakung putih hippadin, pratorimin dan lycobetaine memiliki afinitas dan kestabilan yang lebih baik dibandingkan dengan senyawa pembanding. Hasil drug scan, hippadin, pratorimin dan lycobetain memenuhi kriteria untuk dijadikan sediaan dalam bentuk oral. Dapat disimpulkan senyawa herba bakung putih diprediksi memiliki potensi sebagai senyawa antiinflamasi.
\end{abstract}

Kata kunci : Siklooksigenase, Crinum asiaticum L., penambatan molekul.

\begin{abstract}
Inflammation is a response to tissue injury involving the physiological process of cyclooxygenase enzyme activation which has two isoforms, cyclooxygenase-1 (COX-1) and cyclooxygenase-2 (COX-2) enzymes. The use of anti-inflammatory drugs of Non Steroidal Anti Inflammatory (AINS) and steroid groups has side effects in long-term use. The objective of this study was to find out eight active white herbic alkaloid compounds (Crinum asiaticum L.) to be used as anti-inflammatory by inhibiting COX-1 and COX-2 enzymes. Molecular docking method for the prediction of complex structures of proteins called ligand-protein docking using the PLANTS 1.2 software. where the lowest ChemPLP score which is free energy is the molecular tethering parameter. The herbaceous white herbaceae compound obtained the lowest CHEMPLP score of hippadine $-83.3684 \mathrm{Kcal} / \mathrm{mol}$ and pratorimin $-83.2661 \mathrm{Kcal} / \mathrm{mol}$ and aspirin comparator $-67.3292 \mathrm{Kcal} / \mathrm{mol}$ and paracetamol $-66.3535 \mathrm{Kcal} / \mathrm{mol}$. Molecular docking in COX-2 shows lycobetaine $-87.3991 \mathrm{Kcal} / \mathrm{mol}$ is lower than that of the celecoxib $-85.3729 \mathrm{Kcal} / \mathrm{mol}$ comparator against the cyclooxygenase-2 receptor (COX-2). These
\end{abstract}


results show that the white lycopene alkaloid compounds hyppadine, pratorimin and lycobetaine have better affinity and stability than the comparative compounds. The results of drug scans, hippadin, pratorimin and lycobetaine have the criteria for oral preparations. It can be concluded that herbaceous white herbaceae are predicted to have potential as anti-inflammatory compounds.

Keywords: Cyclooxygenase, Crinum asiaticum L., molecular docking.

DOI: http://10.15408/jkv.v4i2.7686

\section{PENDAHULUAN}

Peradangan (inflamasi) merupakan respon protektif normal terhadap cedera jaringan yang melibatkan berbagai proses fisiologis di dalam tubuh seperti aktivasi enzim, pelepasan mediator, diapedesis atau pergerakan sel darah putih melalui kapiler ke daerah peradangan, migrasi sel, kerusakan dan perbaikan jaringan (Kumar, 2011). Namun, jika peradangan tidak diobati dapat menyebabkan timbulnya penyakit seperti rinitis vasomotor, rematoid artritis, dan aterosklerosis (Ilakkiya et al., 2013).

Mekanisme terjadinya radang sangat dipengaruhi oleh senyawa dan mediator yang dihasilkan oleh asam arakidonat. Bila membran sel mengalami kerusakan oleh suatu rangsangan kimiawi, fisik, atau mekanis maka enzim fosfolipase diaktifkan untuk mengubah fosfolipida yang terdapat di membran sel tersebut menjadi senyawa prostaglandin dan tromboksan (Nørregaard et al., 2015). Enzim siklooksigenase (COX) yang terlibat dalam reaksi memiliki 2 isoform, yaitu COX-1 dan COX-2 (Łanocha-Arendarczyk et al., 2018; Stolfi et al., 2013). Meskipun kedua enzim pada dasarnya berkerja dengan cara yang sama, penghambatan selektif dapat membuat perbedaan dalam hal efek samping. COX-1 dianggap konstitutif enzim, ditemukan pada kebanyakan mamalia sel. Pada COX-2 tidak terdeteksi dalam jaringan normal kebanyakan. COX-2 biasanya khusus untuk jaringan yang meradang, ada banyak iritasi lambung kurang terkait dengan COX-2 inhibitor, dengan penurunan risiko ulserasi lambung (Nandave $e t$ al., 2006). COX-1 terdapat di kebanyakan jaringan antara lain di trombosit, ginjal, dan saluran cerna (Radifar et al., 2013).

Pada umumnya pengobatan yang digunakan untuk mengatasi terjadinya inflamasi adalah obat modern dari golongan Anti Inflamasi Non Steroid (AINS) dan golongan steroid yang berguna untuk mengurangi pembengkakan dan rasa sakit akibat peradangan. AINS terdiri dari kelompok AINS non-selektif yang bekerja dengan menghambat enzim siklooksigenase (COX-1 dan COX-2) sehingga menurunkan produksi prostaglandin, sedangkan kelompok AINS lain (selektif COX-2 inhibitor) bekerja dengan menghambat enzim COX-2. Obat AINS yang tidak menimbulkan efek samping berupa iritasi lambung adalah kelompok AINS yang selektif, dengan menghambat enzim COX-2. Salah satu obat yang menghambat enzim COX-2 adalah Celecoxib (Stolfi et al., 2013). Celecoxib berfungsi menghambat enzim COX-2 yang mengakibatkan sintesa prostaglandin pun terhambat. Karena prostagladin merupakan mediator untuk rasa nyeri pada tubuh (BPOM RI, 2005; Stolfi et al., 2013). Parasetamol tidak mempengaruhi nyeri yang ditimbulkan efek langsung prostaglandin, ini menunjukkan bahwa parasetamol menghambat sintesa prostaglandin dan bukan blokade langsung prostaglandin. Aspirin adalah senyawa antiinflamasi golongan AINS yang memiliki aktivitas penghambat radang dengan mekanisme kerja menghambat biosintesis prostaglandin dari asam arakhidonat melalui penghambatan aktivitas enzim siklooksigenase (Schwier dan Tran, 2016). Tetapi dalam penggunaannya obat-obat ini mempunyai risiko toksisitas gastrointestinal, toksisitas jantung, dan lainnya dalam penggunaan jangka panjang (Oniga et al., 2017; Stolfi et al., 2013). Untuk alasan ini, ada kebutuhan untuk memiliki obat antiinflamasi dengan efek samping yang lebih ringan saat digunakan. Oleh karena itu, tumbuhan lebih banyak dipilih sebagai alternatif yang alami untuk pengobatan berbagai penyakit (Madhavi et al., 2012). Basis data khusus untuk lead compounds berbasis herbal sudah banyak dikembangkan. China, Jepang, Taiwan, dan Indonesia semua memiliki basis data tersebut. Informasi dari basis data herbal tersebut sudah banyak 
dijadikan sumber data untuk penelitian molecular simulation salah satunya adalah penambatan molekuler (molecular docking) (Parikesit et al., 2018)

Herba bakung putih mengandung banyak senyawa alkaloid. Bakung putih (Crinum asiaticum L.) merupakan ramuan obat yang memiliki efek terapi sebagai anti inflamasi (Haque et al., 2014; Patel, 2017). Senyawa lycorin yang terdapat pada ekstrak etanol bakung putih bermanfaat sebagai anti inflamasi (Kim et al., 2006). Akan tetapi tidak hanya lycorin saja senyawa alkaloid yang terdapat pada bakung putih (Kim et al., 2006; Patel, 2017)). Senyawa lain seperti criasbetaine, hippadine, kalbretorine, lycoriside, pratorimine, pratorisine, galanthidine, lycobetaine juga terdapat dalam bakung putih (Refaat et al., 2012) (Gambar 1). Tetapi belum terbukti dari senyawa-senyawa tersebut mana yang lebih baik dibandingkan paracetamol, aspirin dan celecoxib terhadap enzim COX.

Pendekatan tradisional dalam penemuan obat baru memakan waktu yang lama, kurang efisien dan memerlukan biaya yang sangat tinggi (Tripathi dan Misra, 2017). Metode in silico salah satunya penambatan molekul (molecular docking) dapat digunakan untuk membantu menemukan senyawa senyawa yang kemungkinan besar berpotensi sebagai obat, dengan membutuhkan waktu yang relatif singkat (Zukrullah et al., 2012). Pengembangan senyawa aktif dari Crinum asiaticum L. sebagai antiinflamasi (inhibitor enzim COX) juga dapat dilakukan dengan penambatan molekul. Pengembangan tersebut diantaranya mencakup desain senyawa dan interaksi senyawa tersebut dengan enzim atau reseptor. Dalam hal ini, senyawa alkaloid dari Crinum asiaticum L. perlu di uji interaksinya dengan reseptor enzim COX dengan 2 isoform yaitu COX-1 dan COX-2 melalui uji in silico sehingga dapat mengetahui bagaimana senyawa alkaloid pada bakung dapat berikatan dengan reseptor COX dan memiliki afinitas yang lebih baik dibandingkan dengan paracetamol, aspirin dan celecoxib sebagai ligan pembanding melalui metode penambatan molekul dengan membandingkan energy bebas berupa skor CHEMPLP menggunakan software PLANTS 1.2. Secara in silico juga ditentukan senyawa yang memiliki biovaibilitas oral melalui aturan Lipinski Rule of Five.

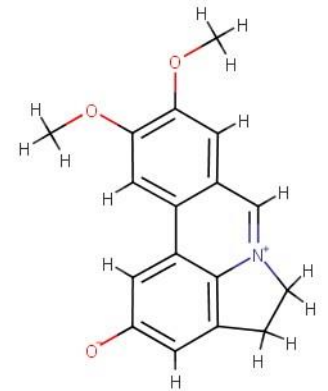

Criasbetaine

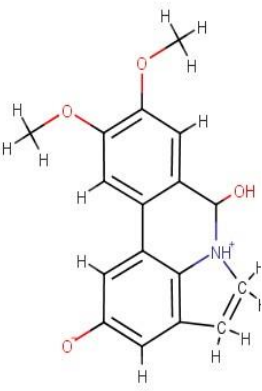

Pratorisine<smiles>[H][Z]([H])([H])Oc1c(O)cc2c(=O)n3ccc4c5ccc6ccc1c2c(c65)c43</smiles>

Pratorimine

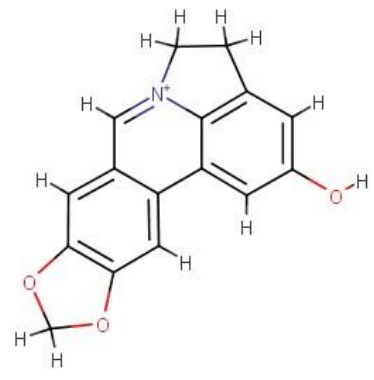

Lycobetaine

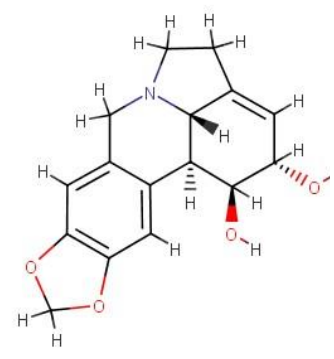

Galanthidine

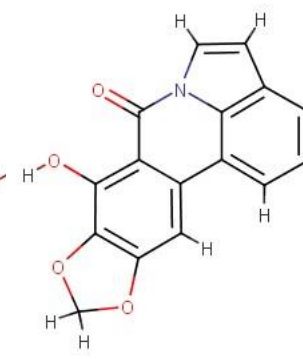

Kalbretorine

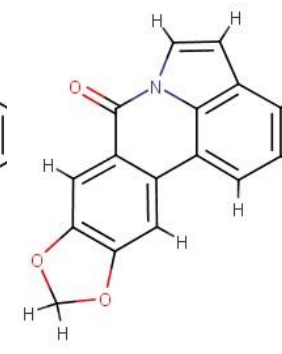

Hippadine

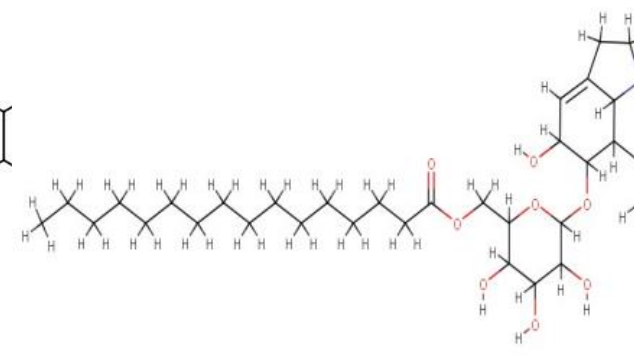

Lycoriside

Gambar 1. Senyawa Alkaloid Herba Bakung (Refaat et al., 2012) 


\section{METODE PENELITIAN}

\section{Alat dan Bahan}

Program penambatan molekul ini bekerja menggunakan LINUX dengan sistem UBUNTU 16 dengan 64 bit. Perancangan ligand dan visualisasi dilakukan melalui Operating System Windows 10. Software yang $\begin{array}{lll}\text { digunakan yaitu PLANTS } & 1.2\end{array}$ (http://www.tcd.uni-

konstanz.de/research/plants.php) yang digunakan untuk penambatan, YASARA 17.4.17 (http://www.yasara.org/viewdl.htm) yang digunakan untuk preparasi protein dan visualisasi, $\quad$ Marvinsketch $\quad 17.9 .0$ (http://www.chemaxon.com/marvin/downloaduser.html) yang digunakan untuk preparasi ligan dan Molegro Molecular Viewer 2.5 yang digunakan untuk visualisasi.

Struktur 3D siklooksigenase-1 (COX1) dan siklooksigenase-2 (COX-2) diunduh dari Protein Data Bank dengan situs http://www.rcsb.org/pdb yang berformat .pdb. Sebelumnya, reseptor yang akan digunakan dilihat pada jurnal yang akan digunakan sebagai bahan acuan. Struktur 3D ligan yang digunakan adalah celecoxib, parasetamol, aspirin dan senyawa Alkaloid dari Crinum asiaticum L., yaitu criasbetaine, hippadine, kalbretorine, lycoriside, pratorimine, pratorisine, galanthidine, lycobetaine yang di rancang dengan Marvin Sketch dengan format .mol2 dan .mrv.

\section{Prosedur Penelitian \\ Penyiapan Struktur Protein}

Pengunduhan makromolekul COX-1 dan COX-2 dari Protein Data Bank dengan situs http://www.rcsb.org/pdb. Makromolekul protein yang dipilih adalah COX-1 (4O1Z) dari Domba (Ovis Aries) dengan format .pdb (Oniga et al., 2017) dan COX-2 (6COX) (Agistia et al., 2013). Makromolekul protein dipisahkan dari pelarut dan ligan atau residu non standar. Pemisahan makromolekul dari molekul yang tidak diperlukan dilakukan dengan menggunakan program YASARA (edit $>$ delete > residu). Penghilangan molekul air (edit $>$ delete $>$ water $)$ dan penambahan hidrogen pada struktur (edit > add > hidrogen to all). Hasil tersebut disimpan dengan nama protein dalam format .mol2.

\section{Preparasi Struktur Ligan}

Struktur ligan diunduh pada situs www. pubchem.ncbi.nlm.nih.gov dalam bentuk 2D. Protonasi diubah pada $\mathrm{pH} 7,4$ dengan menggunakan Marvin Sketch (Calculation > Protonation > Major Microspecies), data yang didapat disimpan dengan format .mrv. File yang telah disimpan dengan format .mrv dibuka dan dilakukan pencarian konformasi dengan software yang sama lalu disimpan dengan format .mol2 (Calculation > Conformation > Conformer).

\section{Validasi Metode Penambatan Molekul}

Sebelum virtual screening, dilakukan validasi untuk menentukan nilai root mean square deviation (RMSD). Validasi menggunakan program YASARA (Analyze > RMSD > Molecule) dengan memasukan ligan spesifik dan reseptor dengan format .mol2. Sebuah protokol diterima apabila RMSD heavy atom sebesar kurang dari 2.0 Angstrom.

\section{Penambatan Molekul dengan PLANTS 1.2}

Docking dilakukan pada sistem operasi Linux karena Program PLANTS 1.2 hanya dapat digunakan didalam Linux. Hasil preparasi ligan dan reseptor dipindahkan dalam format .mol2. Pada langkah selanjutnya untuk mencari sisi pengikatan didapat dengan perintah "./PLANTS --mode bind ref_ligand.mol2 5 protein.mol2". Untuk menjalankan proses docking dimasukkan perintah "./PLANTS --mode screen plantsconfig". Hasil docking dengan dapat dilihat pada terminal dengan memasukan perintah "cd results/" dilanjutkan dengan "more bestranking.csv" pilih dari 10 konformasi mana yang lebih kecil nilainya.

\section{Analisis dan Visualisasi Penambatan Molekul}

Hasil docking dapat dilihat pada output dalam format notepad. Penentuan konformasi kompleks hasil docking dilakukan dengan memilih konformasi yang memilih skor CHEMPLP atau energi bebas paling rendah. Hasil docking divisualisasi menggunakan software YASARA untuk melihat jarak ikatan hidrogen $<3.5 \AA$. 


\section{Drug Scan}

Drug Scan dilakukan menggunakan https://pubchem.ncbi.nlm.nih.gov/assay/assay. cgi. Analisis dilakukan dengan mengunggah file ligan yang akan diuji dalam format .mol. Kemudian hasil yang didapat diunduh dalam bentuk PDF.

\section{HASIL DAN PEMBAHASAN}

Tahap awal pada proses docking adalah penyiapan struktur protein, pemilihan protein pada situs PDB didasarkan pada protein yang ingin diujikan. Enzim siklooksigenase-1 (COX-1) dan siklooksigenase-2 (COX-2) dalam format .pdb diunduh dari database protein Research Collaboratory for Structural Bioinformatics (RCSB) yang diakses melalui situs http://www.rcsb.org/. Protein yang dipilih untuk COX-1 yaitu kode PDB 4O1Z merupakan kompleks enzim dengan meloxicam (ligan asli) yang merupakan golongan obat NSAID, yang diperoleh dari fraksinasi oleh X-Ray kristalografi dari Domba (Ovis Aries) dan tersusun atas 569 asam amino. Sedangkan protein yang dipilih untuk COX-2 adalah yaitu kode PDB 6COX merupakan komples enzim dengan inhibitor selektif S58 (ligan asli) yang diperoleh dari fraksinasi oleh X-Ray kristalografi dari mencit (Mus muculus) dan tersusun atas 587 asam amino. Struktur protein yang diunduh dari PDB umumnya memiliki struktur protein yang masih mengandung pelarut (air), dan residu lainnya pada proses preparasi akan diperoleh struktur protein tanpa ligan asli dan struktur ligan asli. Struktur protein dengan kode PDB 4O1Z dan 6COX dipilih karena memiliki nilai resolusi yang rendah yaitu $2.4 \AA$ (4O1Z) dan $2.8 \AA$ (6COX). Nilai yang rendah tersebut menunjukkan protein reseptor tersebut memiliki kualitas model yang baik. Selain itu, kode PDB 4O1Z terkompleks dengan senyawa inhibitor nonselektif yaitu meloxicam (MXM) yang memang sudah diujikan secara in vitro terhadap enzim COX-1 pada manusia (Homo sapiens) yang memiliki IC50 1000-36600 nM (www.bindingdb.org/jsp/dbsearch/PrimarySear ch_pdbids.jsp?pdbids_submit=Search\&pdbids $=4 \mathrm{O} 1 \mathrm{Z}$ ). Kode PDB 6COX dipilih karena terkompleks dengan senyawa inhibitor COX-2 S58 yang sudah diujikan pada reseptor enzim COX-2 manusia (Homo sapiens) secara in vitro yang memiliki IC50 sebesar $50 \mathrm{nM}$ (www.bindingdb.org/jsp/dbsearch/PrimarySear
ch_pdbids.jsp?pdbids_submit=Search\&pdbids $=6 \mathrm{COX}$. Struktur protein yang diperoleh adalah protein yang telah kehilangan ligan asli, molekul lain seperti air serta atom-atom tunggal lainnya, sehingga pada proses docking yang berinteraksi hanya senyawa uji dengan protein (Kitchen et al., 2004). Ligan dan molekul air ini harus dihilangkan dari makromolekul protein karena dapat memperpanjang durasi simulasi docking. Penambahan atom hidrogen yang dimaksud adalah memunculkan atom hidrogen yang ada pada struktur sehingga terlihat secara tiga dimensi yang berperan dalam interaksi dengan ligan. Simulasi docking semua proses penyiapan struktur makromolekul protein menggunakan software YASARA.

Ligan yang digunakan dalam penelitian adalah ligan asli, ligan pembanding, dan ligan dari senyawa alkaloid herba bakung (Crinum asiaticum L.),yaitu criasbetain, galanthidin, hippadin, kalbretorin, lycobetain, lycorisid, pratorimin dan pratorisin. Ligan asli yang dipakai adalah ligan yang berada pada COX-1 dari makromolekul 4O1Z adalah meloxicam (MXM) (Oniga et al., 2017), sedangkan untuk COX-2 dari makromolekul 6COX adalah inhibitor selektif (S58). Pemisahan MXM dan S58 dari 4O1Z dan 6COX menggunakan YASARA. Optimasi struktur dilakukan untuk mengubah geometri dari molekul ke energy yang lebih rendah dari suatu sistem dan untuk menghasilkan konformasi yang lebih stabil. Optimasi struktur ligan asli meloxicam, S58 dan ligan senyawa alkaloid herba bakung putih (Crinum asiaticum L.) yang sudah didapat, protonasinya dicek pada pH 7.4 dengan software Marvin Sketch, dengan maksud menyesuaikan kondisi $\mathrm{pH}$ tubuh, ligan disesuaikan dengan $\mathrm{pH}$ tubuh, karena proses docking meniru reaksi yang terjadi didalam tubuh sehingga didapat hasil yang optimal (Agistia et al., 2013). Merubah ligan asli dan ligan senyawa alkaloid pada format .mrv menjadi sepuluh bentuk 3D yang mempunyai energi bebas yang berbeda pada setiap bentuknya, proses ini juga dapat disebut optimasi. Pada proses optimasi ligan asli dan ligan senyawa alkaloid telah melalui proses pengulangan pencarian energi bebas, sehingga didapat sepuluh konformasi 3D yang mempunyai energi bebas yang optimal untuk selanjutnya dilakukan proses docking.

Identifikasi protokol docking yang tepat merupakan langkah kunci untuk 
memperoleh validitas pose docking (Oniga et al., 2017). Validasi metode docking pada penelitian ini dilakukan dengan me-redocking ligan asli pada kelompok protein yang diunduh dari situs PDB (Protein Data Bank). Untuk evaluasi validasi, parameter yang dilihat adalah RMSD (Root Mean Square Deviation) dan pose secara visual (Moitessier et al., 2008). RMSD merupakan pengukuran dua pose dengan membandingkan posisi atom antara struktur eksperimental dengan struktur yang di docking atau yang di prediksi (Hawkins et al., 2008) nilai RMSD < 2,0 biasanya digunakan sebagai kriteria kesuksesan metode docking (Hevener et al., 2009; Jain dan Nicholls, 2008; Moitessier et al., 2008)). Hasil dari validasi penelitian ini didapat nilai RMSD $1.5687 \AA$ untuk reseptor COX-1 kode PDB 4O1Z dan nilai RMSD $1.2169 \AA$ untuk reseptor COX-2 kode PDB $6 \mathrm{COX}$, hasil validasi yang didapat membuktikan bahwa kode pdb 4O1Z dan 6COX dapat digunakan karena nilai RMSD tidak lebih dari 2,0 A. Semakin nilai RMSD mendekati nol maka pose salinan ligan asli dengan ligan copy semakin mirip. Hal ini menunjukkan protokol yang dikembangkan diterima dan dapat dikembangkan lebih lanjut untuk skrining virtual dalam usaha penemuan senyawa baru (Purnomo, 2011; Purnomo, 2013). Visualisasi pose validasi antara ligan asli dengan ligan copy menunjukan bahwa struktur dua molekul (Gambar 2) memiliki kemiripan posisi dan sudut dari setiap atomnya. Hal ini berarti konformasi struktur ligan asli dari PDB dengan ligan copy hasil docking mirip dan terpilih dengan baik (Adelina, 2014). Pada RMSD > $2.0 \AA$ akan terlihat dua molekul yang berbeda secara signifikan jika dilihat dari sudut dan posisinya, meskipun memiliki jumlah atom yang sama.

Docking merupakan metode simulasi untuk mengetahui orientasi antara ligan dengan reseptor. Sisi pengikatan COX-1 untuk reseptor $4 \mathrm{O} 1 \mathrm{Z}$ yang telah diketahui pada saat penambatan ulang (redocking) sehingga dapat diketahui titik pusat kordinat yang didapat dengan nilai $\mathrm{x}=252.107 \AA, \mathrm{y}=106.98 \AA, \mathrm{z}=$ $4.70794 \AA$ dan pada radius $=11.9576 \AA$. Sedangkan COX-2 untuk 6COX titik pusat kordinat yang didapat dengan nilai $\mathrm{x}=23,6651$ $\AA, y=23.3126 \AA, z=47.8865 \AA$ dan pada radius $=11.3323 \AA$ A. Hasil docking yang diperoleh antara COX-1 dan COX-2 dengan ligan pada Bakung Putih dapat dilihat pada
Tabel 1. Penambatan molekul bertujuan untuk mengetahui orientasi antara ligan dan ligan asli terhadap enzim COX-1 dan COX-2 untuk membentuk ikatan yang stabil. Adapun parameter kestabilan yang ditentukan adalah energi bebas Gibbs $(\Delta \mathrm{G})$ dan interaksi ikatan kimia yang terbentuk. Docking merupakan pendekatan untuk desain rasional obat menggunakan komputasi untuk menguji aktivitas biologis suatu senyawa (Reddy dan Reddy, 2013). Penambatan molekul banyak digunakan untuk memprediksi apakah suatu senyawa memiliki aktivitas atau tidak, serta dapat berguna dalam pengembangan senyawa dengan aktivitas yang lebih baik. Kode reseptor yang digunakan harus sudah tervalidasi dengan nilai RMSD $<2.0 \AA$ hal ini menunjukkan protokol yang dikembangkan diterima dan dapat dikembangkan lebih lanjut untuk skrining virtual dalam usaha penemuan senyawa baru. Proses docking, memerlukan ligan senyawa alkaloid dalam format .mol2 yaitu ligan yang sudah diminimasi di marvin sketch sehingga akan menghasilkan 10 konformasi bentuk 3D dengan energi bebas yang berbeda. Software yang digunakan untuk docking adalah PLANTS1.2 dalam operating system linux. Proses docking tidak dapat dilakukan sekaligus tapi secara bergantian antara ligan senyawa alkaloid. Penambatan molekul bekerja pada dua sistem : windows dan linux sehingga perlu prosedur khusus untuk mengamankan hasil penambatan molekul agar tidak menganggu proses docking selanjutnya.

Satu kali proses docking akan menghasilkan sepuluh konformasi terbaik ligan dari kompleks protein-ligan yang kemungkinan terjadi. Sepuluh konformasi tersebut dipilih konformasi yang memiliki skor CHEMPLP yang terkecil. Skor CHEMPLP yang dihasilkan pada saat kompleks proteinligan terbentuk dapat menunjukkan afinitas dari ligan terhadap reseptor. Semakin tinggi afinitas dari suatu ligan terhadap protein, maka skor CHEMPLP akan semakin kecil, sebaliknya apabila skor CHEMPLP semakin besar maka afinitas semakin kecil. Tabel 1 adalah nilai energi bebas dari masing-masing ligan terhadap protein $\mathrm{COX}-1$ dan $\mathrm{COX}-2$ sebagai reseptor. Hasil docking yang memprediksi interaksi senyawa criasbetain, galanthidin, hippadin, kalbretorin, lycobetain, lycorisid, pratorimin dan pratorisin dengan enzim COX-1 dari protein yang memiliki kode 
PDB 4O1Z yang terkompleks dengan meloxicam (Tabel 1), dapat diketahui bahwa nilai skor dari beberapa senyawa tersebut memiliki skor CHEMPLP lebih kecil dibandingkan dengan ligan asli meloxicam, karena makin kecil skor suatu hasil docking berarti komplek protein-ligan makin stabil sehingga ligan senyawa makin poten. Jika dibandingkan dengan pembandingnya (parasetamol dan aspirin) maka nilai skor CHEMPLP parasetamol dan aspirin lebih tinggi dibandingkan dengan criasbetain, galanthidin, hippadin, kalbretorin, lycobetain, lycorisid, pratorimin dan pratorisin. Pada senyawa lycorisid terjadi ketidakstabilan skor energi pada konformasi di setiap pengulangan docking untuk memiliki interaksi kestabilan yang baik adalah adanya peran gugus fungsi, ikatan hidrogen (jumlah ikatan hidrogen dan panjang ikatan hidrogen) yang terbentuk, dan daerah interaksi hidrofob (Bissantz et al., 2010; Patil et al., 2010). Senyawa criasbetaine, galanthidin, hippadin, kalbretorin, lycobetain, pratorimin dan pratorisin mempunyai skor CHEMPLP yang stabil pada konformasinya. Hippadin dan pratorimin merupakan senyawa prediksi yang paling poten dibandingkan dengan pembanding dan ligan asli nya untuk dijadikan agen anti inflamasi.

Berdasarkan Tabel 1 interaksi dengan COX-2 dapat dibandingkan antara ke-8 ligan tersebut score CHEMPLP criasbetaine, galanthidine, hippadine, kalbretorine, prastorimine dan pratorisine lebih besar daripada celecoxib sebagai pembanding dan ligan lainnya yaitu lycobetaine dan lycorisidenilai energi bebas lebih kecil daripada celecoxib. Dibandingkan dengan parasetamol dan aspirin, delapan ligan senyawa alkaloid bakung putih memiliki score

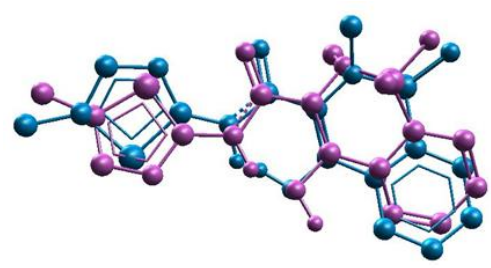

CHEMPLP yang lebih kecil. Hasil ini dapat diartikan bahwa lycobetaine dibandingkan dengan celecoxib mempunyai ikatan yang lebih stabil dan afinitas yang lebih baik terhadap reseptor COX-2. Pada senyawa lycoriside terjadi ketidakstabilan score CHEMPLP pada lima kali pengulangan penambatan, dengan berbeda score CHEMPLP terkecil pada setiap konformasi. Sedangkan enam ligan lainnya memiliki ikatan yang kurang stabil dengan reseptor jika dibandingkan dengan celecoxib. Hal ini menunjukkan lycobetaine memiliki afinitas lebih baik daripada celecoxib. Visualisasi hasil penambatan molekul antara ligan dengan reseptor COX-1 dan COX-2 dapat dilihat pada Tabel 2 dan Gambar 2 dan 3.

Interaksi reseptor dengan ligan yang terbentuk setelah proses penambatan divisualisasikan dengan menggunakan software molegro molecular viewer. Garisgaris putus mendeksripsikan ikatan hidrogen yang terjadi antara residu dengan gugus pada ligan. Pengamatan interaksi residu (asam amino) bertujuan untuk mengidentifikasi interaksi yang terjadi antara ligan dan reseptor. Ikatan hydrogen merupakan ikatan yang unik karena hanya atom hydrogen yang dapat mengemban muatan positif pada $\mathrm{pH}$ fisiologis sembari masih terikat secara kovalen dalam molekul dan atom hidrogen merupakan atom yang cukup kecil untuk berdekatan dengan atom elektronegatif kedua (Rollando, 2017). Ikatan hidrogen cukup penting untuk aktivitas biologis. Ikatan hidrogen merupakan interaksi yang dapat menstabilkan ikatan ligan dan ikatan reseptor. Interaksi lain antara ligan dan reseptor yang dapat meningkatkan kestabilan konformasi adalah interaksi elektrostatik dan interaksi van der walls.

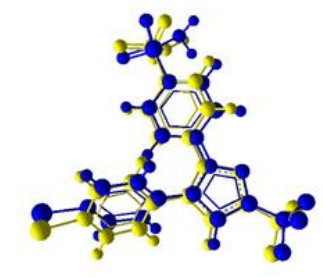

Gambar 2. Visualisasi Superpose Ligan Asli dengan Ligan Copy Menggunakan Software Molegro Molecular Viewer. Keterangan : (a) Struktur Meloxicam (4-hydroxy-2-methyl-N-(5-methyl-1,3-thiazol-2-yl)2H-1,2-benzothiazine-3-carboxamide 1,1-dioxide), Ligan asli berwarna ungu dan ligan copy berwarna biru, (b) S58 (1-phenylsulfonamide-3-trifluoromethyl-5-parabromophenylpyrazole), ligan asli berwarna kuning, ligan copy warna biru 
Tabel 1. Hasil Penambatan Molekul antara Ligan Pembanding dan Ligan Bakung Putih dengan COX-1 dan COX-2 Menggunakan Software PLANTS

\begin{tabular}{lcc}
\hline Ligan & \multicolumn{2}{c}{ Skor CHEMPLP (Kkal/mol) } \\
\cline { 2 - 3 } & Enzim COX-1 (401Z) & Enzim COX-2 (6COX) \\
\hline Ligan Asli 4O1Z MXM (Meloxicam) & -79.8619 & - \\
Ligan Asli 6COX S58 & - & -77.4746 \\
Ligan Pembanding Paracetamol & -66.3535 & -67.4422 \\
Ligan Pembanding Aspirin & -67.3292 & -71.9260 \\
Ligan Pembanding Celecoxib & - & -85.3729 \\
Criasbetain & -70.4006 & -71.9671 \\
Galanthidin & -75.5672 & -81.5418 \\
Hippadin & -83.3684 & -80.7919 \\
Kalbretorin & -80.9120 & -81.2413 \\
Lycobetain & -82.7950 & -87.4009 \\
Lycorisid & -71.1068 & -87.2719 \\
Pratorimin & -83.2661 & -78.4331 \\
Pratorisin & -71.5087 & -76.2386 \\
\hline
\end{tabular}

Tabel 2. Hasil Visualisasi Penambatan Molekul Antara Ligan Pembanding dan Ligan Bakung Putih dengan COX Menggunakan Software PLANTS

\begin{tabular}{lccc}
\hline \multicolumn{1}{c}{ Ligan } & $\begin{array}{c}\text { Residu AsamAmino } \\
\text { yang Berikatan }\end{array}$ & $\begin{array}{c}\text { Jarak Ikatan } \\
(\mathbf{A})\end{array}$ & Gugus Fungsi yang Berikatan \\
\hline $\begin{array}{l}\text { Reseptor COX-1 (4O1Z) } \\
\text { Aspirin }\end{array}$ & - & - & \\
Parasetamol & Tirosin 385 & 1.60 & Atom O pada Gugus aldehida \\
& Tirosin 385 & 1.77 & Atom N pada Gugus aldehida \\
& Tirosin 348 & 3.00 & Atom O pada Gugus aldehida \\
Hippadine & Tirosin 385 & 2.82 & Atom N pada Gugus amida \\
& Tirosin 385 & 3.06 & Atom N pada Gugus amida \\
& Histidin 386 & 3.00 & Atom O pada Gugus Eter \\
Pratorimine & Histidin 386 & 2.81 & Atom O pada Gugus hidroksi \\
& Tirosin 385 & 2.62 & Atom N pada Gugus amida \\
Reseptor COX-2 (6COX) & Tirosin 385 & 3.09 & Atom N pada Gugus amida \\
Celecoxib & Serine530 & 2.5366 & Atom O pada Gugus Sulfonamida \\
& Serine530 & 3.0342 & Atom O pada Gugus Sulfonamida \\
& Serine 530 & 3.1561 & Atom N pada Gugus Sulfonamida \\
Lycobetaine & Threonine 206 & 2.7295 & Atom O pada Gugus Phenol \\
& Phenylalanine205 & 2.4437 & Atom N pada Gugus Phenol \\
& Phenylalanine 205 & 3.3187 & Atom O pada Gugus Phenol \\
& Histidin 207 & 2.7495 & Atom N pada Gugus Phenol \\
\hline
\end{tabular}

Berdasarkan Tabel 2 dapat dilihat perbandingan residu dari dua ligan terbaik serta pembanding aspirin dan parasetamol setelah dilakukan proses docking. Pada ligan pembanding parasetamol (Gambar 2b) berikatan dengan Tirosin 385 dan Tirosin 348 yang terdapat pada dua atom $\mathrm{O}$ jarak ikatan $1.60 \AA$ dan $1.77 \AA$ dan satu atom $\mathrm{N}$ jarak ikatan $3.0 \AA$ yang terbentuk pada gugus fungi aldehida, tetapi pada ligan pembanding aspirin tidak terjadi ikatan hidrogen (Gambar 2a), ikatan kimia yang memungkinkan terjadi adalah ikatan-ikatan lemah seperti ikatan van der Waals. Pada dua skor terbaik ligan senyawa herba bakung putih (Crinum asiaticum L.) diantaranya hippadin (Gambar 
2c) berikatan dengan Tirosin 385 dan Histidin 380 yang terdapat pada dua atom $\mathrm{N}$ jarak ikatan $2.82 \AA$ dan $3.06 \AA$ yang terbentuk pada gugus fungsi amida dan satu atom $\mathrm{O}$ jarak ikatan $3.0 \AA$ pada gugus eter, pratorimin (Gambar 2d) berikatan dengan Histidin 386 dan Tirosin 385 yang terdapat pada atom $\mathrm{O}$ jarak ikatan $2.81 \AA$ pada gugus fungi hidroksi serta dua atom $\mathrm{N}$ jarak ikatan $2.62 \AA$ dan 3.09 $\AA$ pada gugus fungsi amida. Hal ini dapat disimpulkan bahwa senyawa hippadin dan pratorimin memiliki interaksi lebih baik dibandingkan dengan parasetamol dan aspirin

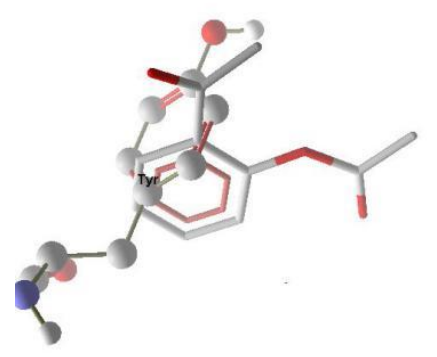

(a)

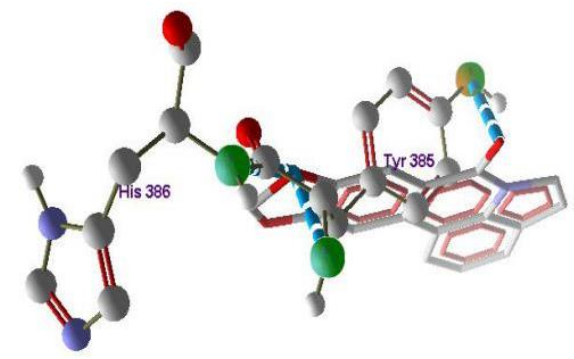

(c) karena memiliki interaksi kestabilan yang baik adalah adanya peran gugus fungsi, ikatan hidrogen (jumlah ikatan hidrogen dan panjang ikatan hidrogen) yang terbentuk (Bissantz et al., 2010; Patil et al., 2010). Ikatan hidrogen dapat terjadi antara intermolekul dan intramolekul, rentang ikatan hidrogen yang baik adalah pada 2.5-3.5 $\AA$ (Syahputra et al., 2014), sehingga senyawa hippadin memiliki ikatan yang lebih baik dari pada parasetamol, yang memungkinkan bahwa akan lebih poten untuk sebagai agen antiinflamasi dengan menghambat enzim siklooksigenase-1.

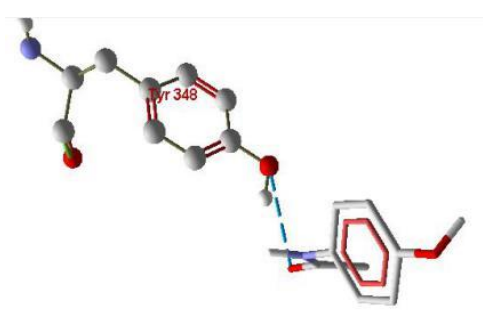

(b)

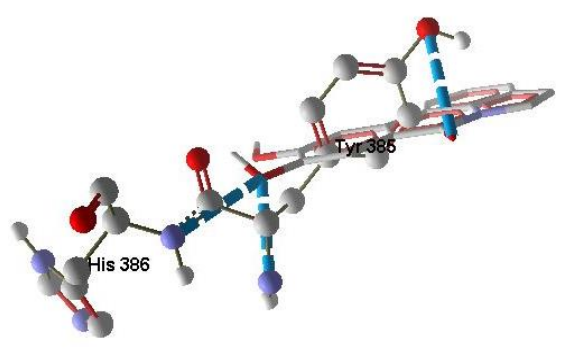

(d)

Gambar 2. Visualisasi Kontak Residu Ligan dengan Reseptor Siklooksigenase-1 (COX-1) Menggunakan Software Molegro Molecular Viewer

Keterangan: (a) Aspirin, Ligan berinteraksi dengan residu Tirosin (b) Paracetamol, Ligan berinteraksi dengan residu Tirosin, (c) Hippadin, Ligan berinteraksi dengan residu Tirosin dan Histidin, (d) Pratorimin, Ligan berinteraksi dengan residu Histidin dan Tirosin. Atom berbentuk bulat berwarna merah adalah aseptor dan biru adalah donor, garis biru putus-putus adalah jarak ikatan.

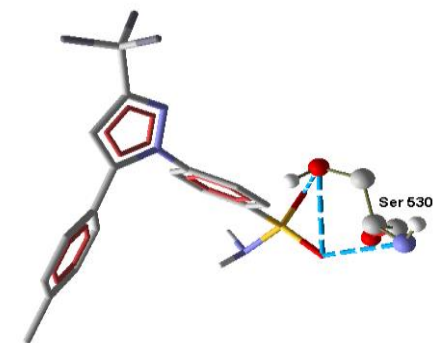

(a)

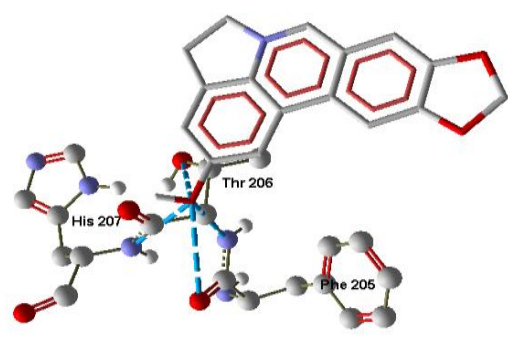

(b)

Gambar 3. Visualisasi Kontak Residu Ligan dengan Reseptor Siklooksigenase-2 (COX-2) Menggunakan Software Molegro Molecular Viewer. Keterangan: (a) Celecoxib, ligan berinteraksi dengan residu Serin, (b) Lycobetain, ligan berinteraksi dengan residu Histidin, Fenilalanin dan Treonin. Atom berbentuk bulat berwarna merah adalah aseptor dan biru adalah donor, garis biru putus-putus adalah jarak ikatan. 
Perbandingan residu pada reseptor COX-2 dari ligan terbaik dan celecoxib setelah dilakukan proses penambatan (Tabel 2). Pada sisi pengikatan yang telah ditentukan, ligan pembanding celecoxib berikatan hanya pada serine 530, dengan membentuk ikatan dua atom $\mathrm{O}$ dan satu atom $\mathrm{N}$ dengan gugus sulfonamida pada ligan celecoxib (Gambar 3a), sedangkan pada ligan lycobetaine terdapat interaksi dengan threonine 206, phenylalanine 205 dan Histidin 207 dengan gugus fenol pada lycobetaine (Gambar 3b). Hal ini dapat disimpulkan bahwa senyawa lycobetain memiliki interaksi lebih banyak dengan reseptor COX-2 dibandingkan dengan celecoxib dan lycobetain memiliki jarak ikatan yang lebih kecil. Semakin kecil jarak ikatan berarti bahwa ikatan yang terjadi semakin kuat dan tidak mudah untuk terlepas, begitu sebaliknya semakin besar jarak ikatan yang terjadi maka semakin lemah dan mudah terlepas. Dari data yang sudah didapat, senyawa lycobetaine memiliki ikatan yang lebih kuat dan stabil daripada celecoxib dan memungkinkan memiliki peran sebagai inhibitor COX-2 yang lebih baik dibandingkan dengan celecoxib sebagai pembanding. Pada asam amino yang berikatan dengan celecoxib dan lycobetaine tidak dapat diartikan sebagai sisi aktif dari reseptor, karena proses docking merupakan virtual screening pada senyawa aktif untuk melihat kestabilan dan afinitas senyawa terhadap reseptor.

Drug-likeness adalah konsep kualitatif yang digunakan untuk menggambarkan kemiripan suatu senyawa sebagai kandidat obat seperti, keseimbangan kompleks dari berbagai sifat molekuler dan ciri struktural yang menentukan apakah molekul tertentu serupa dengan obat yang telah diketahui. Sifat molekuler ini terutama hidrofobisitas, distribusi elektronik, karakteristik ikatan hydrogen, ukuran molekul dan fleksibilitas dan sifat farmakofor lainnya memepengaruhi perilaku molekul dalam organisme hidup, termasuk bioavaibilitas, sifat penghantaran, afinitas terhadap protein, reaktivitas, toksisitas, stabilitas metabolic lainnya (Leeson, 2016; Mishra et al., 2017). Aturan 5 (Ro5) atau Lipinski Rule of Five adalah seperangkat pedoman silico yang diterapkan pada penemuan obat untuk memprioritaskan senyawa dengan kemungkinan peningkatan penyerapan oral yang tinggi (Doak et al., 2014). Lipinski Rule of Five dapat digunakan untuk menentukan farmakokinetik suatu senyawa sebagai kandidat obat (Benet et al., 2016). Drug-likeness yang dievaluasi oleh Lipinski Rule of Five membahas empat parameter parameter fisikokimia sederhana (berat molekul $\leq 500, \log \mathrm{P} \leq 5$, donor ikatan hydrogen $\leq 5$, akseptor ikatan hidrogen $\leq 10$ ) yang berhubungan dengan $90 \%$ obat aktif oral yang telah melewati status klinis fase II (Lipinski, 2004; Lipinski, 2016).

Sifat fisikokimia ligan hippadin, pratorimin dan lycobetain (Tabel 4) berdasarkan aturan Lipinski digunakan untuk menentukan karakter hidrofobik atau hidrofilik suatu senyawa untuk melalui membran sel secara difusi pasif. Nilai log $\mathrm{P}$ hippadin, pratorimin dan lycobetain menyatakan koefisien kelarutan dalam lemak/air yang memiliki rentang $-0.4 \mathrm{~s} / \mathrm{d} 5$. Berat molekul yang lebih dari 500 Da tidak dapat berdifusi menembus membran sel dengan cara difusi pasif. Semakin besar nilai $\log \mathrm{P}$, maka semakin hidrofobik molekul tersebut. Molekul yang memiliki sifat terlalu hidrofobik cenderung memiliki tingkat toksisitas yang tinggi karena akan tertahan lebih lama pada lipid bilayer dan terdistribusi lebih luas di dalam tubuh sehingga selektifitas ikatan terhadap enzim target menjadi berkurang. Nilai $\log \mathrm{P}$ yang terlalu negatif juga tidak baik karena jika molekul tersebut tidak dapat melewati membran lipid bilayer. Jumlah donor dan akseptor ikatan hidrogen mendeskripsikan semakin tinggi kapasitas ikatan hidrogen, maka semakin tinggi energi yang dibutuhkan agar proses absorpsi dapat terjadi. Secara umum aturan lipinski menggambarkan solubilitas senyawa tertentu untuk menembus membran sel oleh difusi pasif (Lipinski et al., 1997). Topological Polar Surface Area (TPSA) adalah parameter fisiokimia yang sangat berguna dari molekul yang memberikan informasi tentang polaritas senyawa. Parameter ini dievaluasi untuk menganalisis sifat penghantaran obat (Mishra et al., 2017). Nilai TPSA pada hipadin, pratorimin dan lycobetain menunjukan nilai $<60$ yang bioavaibilitasnya dapat diterima karena obat sepenuhnya diserap lebih dari 90\%. Sehingga dapat disimpulkan dua senyawa herba bakung putih (Crinum asiaticum L.) yang memperoleh skor terbaik adalah hippadin, pratorimin dan lycobetain serta memenuhi syarat lipinski dan dapat dijadikan sediaan bentuk oral. 
Tabel 4. Hasil prediksi lipinski terhadap aspirin, paracetamol, hippadin, pratorimin dan lycobetain

\begin{tabular}{|c|c|c|c|c|c|}
\hline \multirow[b]{2}{*}{ Ligan } & \multicolumn{5}{|c|}{ Prediksi Lipinski } \\
\hline & $\begin{array}{c}\mathbf{B M} \\
(\mathrm{g} / \mathrm{mol})\end{array}$ & $\log \mathbf{P}$ & HBD $^{\mathbf{a}}$ & $\mathbf{H B A}^{\mathbf{b}}$ & TPSA \\
\hline Aspirin & 180.159 & 1.2 & 1 & 4 & 63.43 \\
\hline Paracetamol & 151.165 & 0.5 & 2 & 2 & 49.3 \\
\hline Celecoxib & 381.37 & 3.836 & 1 & 6 & 86.36 \\
\hline Hippadin & 263.252 & 3.1 & 0 & 3 & 40.5 \\
\hline Pratorimin & 265.268 & 2.9 & 1 & 3 & 51.5 \\
\hline Lycobetaine & 266.27 & 2.708 & 1 & 3 & 42.57 \\
\hline
\end{tabular}

\section{SIMPULAN}

Senyawa alkaloid herba bakung (Crinum asiaticum L.) memiliki potensi sebagai antiinflamasi terhadap enzim siklooksigenase (COX) yang memiliki 2 isoform yaitu COX-1 dan COX-2 berdasarkan metode penambatan molekul dan dapat dijadikan sediaan oral berdasarkan aturan Lipinski Rule of Five. Senyawa-senyawa tersebut yaitu hippadin dan pratorimin yang memiliki interaksi lebih baik terhadap COX-1 dibandingkan senyawa pembanding yaitu aspirin dan parasetamol, sedangkan lycobetain memiliki interaksi lebih baik terhadap COX-2 dibandingkan senyawa pembandinganya yaitu celecoxib. Untuk mengetahui kestabilan interaksi ikatan disarankan menggunakan simulasi molecular dynamics.

\section{UCAPAN TERIMA KASIH}

Penulis ucapkan terima kasih kepada Lemlitbang UHAMKA atas bantuan berupa dana PPI tahun anggaran 2017 Nomor : 518/F.03.07/2017.

\section{DAFTAR PUSTAKA}

Adelina R. 2014. Uji Molecular Docking Annomuricin E dan Muricapentocin pada Aktivitas Antiproliferasi (Molecular Docking Studies of Annomuricin E and Muricapentocin on Antiproliferation Activity ). Jurnal Ilmu Kefarmasian Indonesia. 12(1): 32-36.

Agistia DD, Purnomo H, Tegar M, Nugroho AE. 2013. Interaction Between Active Compounds From Aegle marmelos Correa. as Anti Inflamation Agent with COX-1 and COX-2 Receptor. Traditional Medicine Journal. 18(2): 80-87.
Benet LZ, Hosey CM, Ursu O, Oprea TI. 2016. BDDCS, the Rule of 5 and drugability. Advanced Drug Delivery Reviews. 101: 8998.

Bissantz C, Kuhn B, Stahl M. 2010. A medicinal chemist's guide to molecular interactions. Journal of Medicinal Chemistry. 53(14): 5061-5084.

BPOM RI. 2005. Informasi Terkait Aspek Keamanan Celebrex (Celecoxib). Jakarta: Badan Pengawas Obat dan Makanan.

Doak B, Over B, Giordanetto F, Kihlberg J. 2014. Oral Druggable Space beyond the Rule of 5: Insights from Drugs and Clinical Candidates. Chemistry \& Biology. 21(9): 1115-1142.

Haque M, Jahan S, Rahmatullah M. 2014. Ethnomedicinal Uses of Crinum Asiaticum : a Review. World Journal of Pharmacy and Pharmaceutical Sciences. 3(9): 119-128.

Hawkins P, Warren G, Skillman A, Nicholls A. 2008. How to do an Evaluation: Pitfalls and Traps. Journal of Computer-Aidid Molecular Design. 22(3): 179-190.

Hevener KE, Zhao W, Ball D M, Babaoglu K, Qi J, White S W, Lee RE .2009. NIH Public Access. Journal of Chemical Information Model. 49(2): 444-460.

Ilakkiya R, Neelvizhi K, Tamil SS, Bharatidasan R, Rekha D. 2013. A comparative study of antiinflammatory activities of certain herbal leaf extracts. International Journal of Pharmacy Ang Integrated Life Sciences. 1(2): 67-77.

Jain A, Nicholls A. 2008. Recommendations for Evaluation of Computational Methods. Journal of Computer-Aidid Molecular Design. 22: 133-139.

Kim Y, Kim K, Park S, Lee S, Kim Y, Kim Y, Kim 
K. 2006. Anti-Inflammantory Activity of Crinum asiaticum Linne var. Japonicum Extract and Its Application as a Cosmeceutical Ingredient. Journal of Cosmetic Science. 59(5): 419-430.

Kitchen DB, Decornez H, Furr JR, Bajorath J. 2004. Docking and scoring in virtual screening for drug discovery: Methods and applications. Nature Reviews Drug Discovery. 3(11): 935-949.

Kumar K. 2011. Evaluation of Wound Healing Activity of Leaves of Crinum asiaticum L. International Journal of Phytotheraphy. 1(1): 16-20.

Łanocha-Arendarczyk N, Baranowska-Bosiacka I, Kot K, Gutowska I, Kolasa-Wołosiuk A, Chlubek D, Kosik-Bogacka D. 2018. Expression and activity of COX-1 and COX2 in acanthamoeba sp.-infected lungs according to the host immunological status. International Journal of Molecular Sciences. 19(1): 1-17.

Leeson P. 2016. Molecular Inflation, Attrition and the Rule of Five. Advanced Drug Delivery Reviews. 101: 22-23.

Lipinski C. 2004. Lead-and Drug-like Compounds: The Rule-of-Five Revolution. Drug Discovery Today: Technologies. 1(4): 337341 .

Lipinski C. 2016. Rule of Five in 2015 and Beyond: Target and Ligand Structural Limitations, Ligand Chemistry Structure and Drug Discovery Project Decisions. Advanced Drug Delivery Reviews. 101: 34-41.

Lipinski C, Lombardo F, Dominy B, Feeney P. 1997. Experimental and Computational Approaches to Estimate Solubility and Permeability in Drug Discovery and Development Settings. Advance Drug Delivery Reviews. 23(1-3): 3-25.

Madhavi P, Rao M, Vakati K, Rahman H, Eswaraiah M. (2012). Evaluation of AntiInflammatory Activity of Citrullus lanatus Seed Oil by In-vivo and In-vitro Models. International Research Journal of Pharmaceutical and Applied Sciences. 2(4): 104-108.

Mishra SS, Sharma CS, Singh HP, Pandiya H. 2017. In Silico Pharmacokinetic and Toxicity Study of Some Selected Antidepressant Drugs. Chemistry Research Journal. 2(1):
$42-45$.

Moitessier N, Englebienne P, Lee D, Lawandi J, Corbeil C. 2008. Towards the Development of Universal, Fast and Highly Accurate Docking Scoring Methods: a Long Way to Go. British Journal of Pharmacology. 153(1): 7-26.

Nandave MD, Ojha SK, Arya DS. 2006. Should Selective COX-2 Inhibitors be Used More? Indian Journal of Pharmaceutical Sciences. 68(3): 281-285.

Nørregaard R, Kwon TH, Frøkiær J. 2015. Physiology and pathophysiology of cyclooxygenase-2 and prostaglandin E2 in the kidney. Kidney Research and Clinical Practice. 34(4): 194-200.

Oniga SD, Pacureanu L, Stoica CI, Palage MD, Crăciun A, Rusu LR, Araniciu C. 2017. COX inhibition profile and molecular docking studies of some 2-(Trimethoxyphenyl)Thiazoles. Molecules. 22(9): 1-15.

Parikesit AA, Nurdiansyah R, Agustriawan D. Telaah Sistematis Terhadap Basis Data Bahan Alam Untuk Pengembangan Produk Suplemen Herbal. Prosiding SEMNASTAN 0, no. 0 (22 January 2018): 62-68. Accessed 28 January 2018

Patel D. 2017. Crinum asiaticum Linn: A Medicinal Herb as Well as Ornamental Plant in Central India. International Journal of Environmental Science \& Natural Resources. 6(1): 1-7.

Patil R, Das S, Stanley A, Yadav L, Sudhakar A, Varma AK. 2010. Optimized hydrophobic interactions and hydrogen bonding at the target-ligand interface leads the pathways of Drug-Designing. PLoS ONE. 5(8): 1-10.

Radifar M, Yuniarti M, Istyastono E. 2013. PyPLLF - dibantu Redocking Indomethacin (R) - Alpha - Etil - Ethanolamide ke Cyclooxigenase-1. Indonesian Journal of Chemistry. 13(3): 283-286.

Reddy BR, Reddy LP. 2013. Harmony Search Optimization for Flexible Docking. International Journal of Innovative Technology And Research. 1(6): 615-616.

Refaat J, Kamel MS, Ramadan MA, Ali AA. 2012. Crinum; An endless source of bioactive principles: a review, part 1. Crinum alkaloids: lycorine-type alkaloids. International Journal of Pharmaceutical Sciences and Research. 
3(7): 1883-1890.

Schwier N, Tran N. 2016. Non-steroidal antiinflammatory drugs and aspirin therapy for the treatment of acute and recurrent idiopathic pericarditis. Pharmaceuticals. 9(17): 1-18.

Stolfi C, De Simone V, Pallone F, Monteleone G. 2013. Mechanisms of action of non-steroidal anti-inflammatory drugs (NSAIDs) and mesalazine in the chemoprevention of colorectal cancer. International Journal of Molecular Sciences. 14(9): 17972-17985.
Syahputra G, Ambarsari L, Sumaryada T. 2014. Simulasi Docking Senyawa Kurkumin dan Analognya Sebagai Inhibitor Enzim 12Lipoksigenase. Jurnal Biofisika. 10(1) : 55-67

Tripathi A, Misra K. 2017. Molecular Docking: A structure-based drug designing approach. JSM Bioinformatics, Genomics and Proteomics. 5(2): 1-5.

Zukrullah M, Aswad M, Subehan S. 2012. Kajian Beberapa Senyawa Antiinflamasi Docking Terhadap Siklooksigenase-2 Secara In Silico. Majalah Farmasi Dan Farmakologi. 16(1): 37-44. 